\title{
Bacterial toxins: a possible cause of cot death
}

\author{
N McKendrick, D B Drucker, J A Morris, D R Telford, A J Barson, B A Oppenheim, \\ B A Crawley, A Gibbs
}

\begin{abstract}
Aim: To test the hypothesis that sudden infant death syndrome (SIDS) may be caused by toxins of commonly occurring bacteria in infants lacking developed immunity.

Methods: Nasopharyngeal microbial isolates from 22 pairs of SIDS cases and healthy infants matched for age (by month), sex, and sampling time (by month) were compared for lethal toxigenicity. Crude toxin preparations were made from isolates cultured on dialysis membrane overlaid on agar, and these preparations were then tested for lethality by intravenous injection into 11 day old chick embryos.

Results: Fifteen (68\%) of the SIDS cases were each found to have at least one lethally toxigenic organism in their nasopharyngeal flora; only eight $(36 \%)$ of the flora of normal infants included a lethally toxigenic species.

Conclusion: Infants who have died of SIDS have a significantly higher $(p<0.05)$ probability than matched healthy infants of having a lethally toxigenic bacterial species in their nasopharyngeal flora.
\end{abstract}

Department of Cell

and Structural

Biology, University of Manchester

N McKendrick

D B Drucker

Department of

Pathology, Lancaster

Moor Hospital,

Lancaster

J A Morris

D R Telford

Department of

Pathology, St Mary's

Hospital, Manchester

A J Barson

Department of

Medical Microbiology,

Withington Hospital,

Manchester

B A Oppenheim

B A Crawley

Department of Public

Health and

Epidemiology,

University of

Manchester

A Gibbs

Correspondence to:

Dr D B Ducker, Department

of Cell and Structural

Biology, University of

Manchester, Turner Dental

School, Manchester

M15 6FH

Accepted for publication

31 July 1991
Theories about sudden death in infancy have been reviewed. ${ }^{5}$ Possible causes include overwhelming intestinal infections which have bee attributed to at least a proportion of cot deaths. Infection with respiratory syncytial virus, par- ticularly in infants aged over three months, has been also been suggested as a "precipitating factor" of sudden death. ${ }^{6}$ Infection, however, may only be one of several contributing factors in SIDS. Anaphylaxis and apnoea are possible consequences of infection. Bacon and others have proposed that the combination of excessive wrapping and mild infection could produce potentially fatal heat stroke in infants. ${ }^{9}$ More recently, overheating and the prone sleeping position have been shown to be independently associated with an increased risk of SIDS. ${ }^{10}$

Although specific toxigenic bacteria, such as Clostridium botulinum or Escherichia coli, have been reported in SIDS, ${ }^{811} 12$ it has only recently been suggested that SIDS may be caused by an overwhelming toxaemia produced by bacteria which are normal members of the infant's microbial flora. ${ }^{13}$

Many of the bacteria found in the respiratory tract such as staphylococci, streptococci, and Gram negative bacilli produce potentially lethal toxins. These bacterial toxins, absorbed from the upper respiratory tract, may specifically be a cause of SIDS. ${ }^{13}$ The common bacterial toxin hypothesis assumes that the toxins produced by bacteria of the normal microbial flora are common. The infant is protected from the fatal action of these toxins in the early weeks of life by maternal immunoglobulins but then becomes increasingly susceptible until its own immunity is fully established. Because the toxins are common, infants normally become colonised early in life and develop immunity to them. If, however, the first exposure to a particular toxingenic bacterium were to coincide with a viral infection in a hypoimmune infant then the resulting excessive bacterial growth and toxin production in the nasopharynx could lead to sudden death. The hypothesis closely predicts the characteristic unimodal age incidence curve of SIDS and is consistent with the epidemiological evidence. ${ }^{13}$

Comparison of the nasopharyngeal microbial flora in babies who have died of SIDS and matched healthy infants has shown significantly higher isolation rates of streptococci and enterobacteria from the SIDS cases. ${ }^{14}$ These results indicate that the nasopharyngeal microbial flora is disordered in SIDS.

\section{Methods}

The subjects of this study were babies aged between one week and one year who had died suddenly and unexpectedly. The dead infants 
were examined at necropsy either at St Mary's Hospital, Manchester, or at Lancaster Moor Hospital, Lancaster. A medical history was obtained and a detailed necropsy performed with careful macroscopic dissection and histological examination of the tissues. Cases were excluded from the study if antibiotics had been given the week before death or if a definite cause of death was identified. Samples of blood, lung, spleen and cerebrospinal fluid were also cultured to exclude invasive bacterial infection. Nasopharyngeal secretions were sampled by pernasal swabs before necropsy and as soon as possible after death. In most cases this was carried out within a few hours of discovery of death; if delay was unavoidable the body was refrigerated. ${ }^{14}$

The matched healthy infants were part of an existing prospective study of the normal nasopharyngeal flora in infants aged two weeks to six months. ${ }^{14}$ All were healthy infants attending well-baby clinics, who had been born at term, were gaining weight normally, were free of known disease and had no clinical evidence of a recent viral infection. Care was taken to ensure that the posterior nasopharynx was sampled and the swabs were investigated in the same way as those from babies who had died of SIDS. ${ }^{14}$

Pairs of SIDS babies and normal infants were matched for age (by month), sex, and sampling time (by month). Where pairing of the closest matching healthy infant was not possible, the next closest age matched infant was paired.

\section{BACTERIAL FLORA}

The pernasal swabs obtained were used to inoculate various standad bacteriological culture media. ${ }^{14}$ All types of colonies were recorded, subcultured, identified and stored without any subjective assessment being made of their possible clinical importance. Isolates were identified initially by colonial morphology, Gram morphology, and primary microbiological tests. For species level identification, isolates were processed through the following commercial identification kits (all supplied by API-bioMérieux (UK) Ltd., Basingstoke, unless indicated otherwise): enterobacteria, API $20 \mathrm{E}$; strepococci, API 20 STREP; staphylococci, API STAPH; Gram negative cocci, API quadFERM or RapID NH (Innovative Diagnostic Systems, Inc., Atlanta); Inperfect fungi, API 20 C AUX. Coryneform bacteria were identified by the results of biochemical tests as detailed elsewhere. ${ }^{15}$ All isolates were preserved at $-80^{\circ} \mathrm{C}$.

\section{TESTING FOR TOXIGENICITY}

These isolates were screened for lethal toxin production using a chick enbryo assay system. ${ }^{16}$ The method used for crude toxin preparation is based on that described by Hallander. ${ }^{18}$

The isolates were grown on blood agar or on chocolate agar (if essential) which had been overlaid with dialysis membrane. After overnight growth the supra-membrane bacterial growth and extracellular products, including putative toxins, were washed off using distilled Hanks's Balanced Salt Solution (HBSS), (Sigma; Poole, Dorset). The bulk of the bacterial cells were then removed by centrifugation and the supernatant fluid was sterilised by filtration through a $0.2 \mu \mathrm{m}$ pore membrane filter (Gelman Sciences). For parity between different strains, the filter sterilised crude toxin preparation was diluted with HBSS to a concentration equivalent to a notional absorbance (at $\lambda 585 \mathrm{~mm}$ ) of the original bacterial suspension $\equiv 5 \cdot 0$. This concentration was chosen in the light of earlier studies on toxigenicity in germ free rats. ${ }^{19}$

The technique of intravenous inoculation of 11 day old chick embryos has been described by Eichhorn. ${ }^{20}$ Each egg was injected intravenously with $100 \mu \mathrm{l}$ of sterile crude toxin preparation, or alternatively HBSS as a toxin free negative control solution. After incubation at $38^{\circ} \mathrm{C}$, usually of 18 hours' duration, eggs were re-examined by candling and embryo survival recorded. Samples of blood from the dead embryos were taken and cultured overnight on blood agar aerobically at $37^{\circ} \mathrm{C}$ to ensure that death had not resulted from microbial infection. Two separate toxin preparations were tested for each bacterial isolate, using a minimum of 10 eggs.

\section{ENDOTOXIN ASSAYS}

Concentrations of endotoxin in toxin preparations were measured by the chromogenic modification of the Limulus amoebocyte assay using the Coatest endotoxin kit (Kabi Diagnostica, Kabi Vitrum Ltd., Uxbridge, England).

\section{Results}

Table 1 shows the matching of SIDS cases with healthy infants. Obviously, potential pairs of infants were excluded if matching was poor. Of the pairs matched by age, $36 \%$ were matched to the same week, $59 \%$ to within one week. All but two pairs could be age matched to within two weeks. All pairs were sampled in the matching month of year and with a single exception it was possible to match the sex of infant. The microbial species isolated from the 22 pairs of SIDS babies and matched healthy infants are shown in table 2, together with their toxigenicity. Isolation of Staphylococcus aureus was higher in cases of SIDS (64\%) than normal infants $(45 \%)$. The numbers of streptococcal and enterobacterial isolations were also higher in SIDS cases; furthermore, the variety of species within either group of organisms was greater in the SIDS group. Conversely, the numbers of both coryneform baceria and Moraxella catarrhalis isolated were higher in normal than SIDS infants. Of the total of 57 SIDS isolates tested, $19(34 \%)$ proved to be lethal whereas of the 49 isolates from normal infants, only $11(22 \%)$ proved lethal.

For each SIDS baby or normal infant, the predominant microbial species isolated from a pernasal swab is listed in table 1 . It is important to emphasise that this is not an exhaustive investigation of the nasopharyngeal flora of any infant but of the dominant representative 
Table 1 Lethality to 11 day old chick embryos of crude toxin preparations from predominant nasopharyngeal micro-organisms isolated from SIDS cases and normal infantst

\begin{tabular}{|c|c|c|}
\hline Case No & SIDS cases & Normal infants \\
\hline 1 & $\begin{array}{l}17 \text { weeks, M, February } \\
\text { H parainfluenzae II: } 11 / 11^{\star} \\
\text { Lacto lactis cremoris: } 0 / 12\end{array}$ & $\begin{array}{l}17 \text { weeks, } M, \text { February } \\
S \text { sanguis II: } 0 / 10 \\
C \text { hofmanniit: } 0 / 10\end{array}$ \\
\hline 2 & $\begin{array}{l}20 \text { weeks, } M, \text { September } \\
S \text { aureus a\$: } 0 / 11 \\
S \text { aureus b\$: } 0 / 10 \\
S \text { mitis: } 1 / 9\end{array}$ & $\begin{array}{l}19 \text { weeks, } M \text {, September } \\
M \text { (B) catarrhalis: } 10 / 10^{\star} \\
H \text { influenzae: } 10 / 10^{\star}\end{array}$ \\
\hline 3 & $\begin{array}{l}4 \text { weeks, } M, \text { October } \\
S \text { aureus: } 11 / 16^{\star} \\
S \text { epidermidis: } 1 / 11\end{array}$ & $\begin{array}{l}2 \text { weeks, } M, \text { October } \\
\text { S epidermidis: } 0 / 12 \\
\text { S aureus: } 1 / 9 \\
C \text { striatum: } 1 / 11\end{array}$ \\
\hline 4 & $\begin{array}{l}9 \text { weeks, } \mathrm{F}, \text { March } \\
\text { Torulopsis candida: } 0 / 12 \\
\text { S pneumoniae } 2: 2 / 11 \\
S \text { epidermidis: } 1 / 11\end{array}$ & $\begin{array}{l}10 \text { weeks, } M, \text { March } \\
\text { Escherichia coli: } 12 / 12^{\star} \\
M(B) \text { catarrhalis: } 12 / 12^{\star}\end{array}$ \\
\hline 5 & $\begin{array}{l}25 \text { weeks, F, June } \\
\text { S aureus: 0/11 } \\
\text { Klebsiella oxytoca: } 8 / 9^{\star} \\
\text { S pneumoniae II: } 0 / 10\end{array}$ & $\begin{array}{l}20 \text { weeks, } \mathrm{F} \text {, June } \\
S \text { pneumoniae I:2/11 } \\
S \text { mitis: } 1 / 10\end{array}$ \\
\hline 6 & $\begin{array}{l}15 \text { weeks, } M, \text { September } \\
\text { S aureus: } 1 / 11 \\
\text { Kl aerogenes: } 11 / 11^{\star} \\
\text { E coli: } 11 / 11^{\star} \\
\text { Candida albicans: } 0 / 12\end{array}$ & $\begin{array}{l}17 \text { weeks, } M, \text { September } \\
S \text { aureus: } 0 / 11 \\
C \text { hofmannii: } 1 / 15 \\
\text { Ent aerogenes: } 11 / 11^{\star}\end{array}$ \\
\hline 7 & $\begin{array}{l}17 \text { weeks, } \mathrm{F}, \text { December } \\
S \text { aureus: } 11 / 12^{\star}\end{array}$ & $\begin{array}{l}15 \text { weeks, } \mathrm{F}, \text { December } \\
M(B) \text { catarrhalis: } 4 / 15 \\
S \text { pneumoniae } \mathrm{I}: 1 / 10\end{array}$ \\
\hline 8 & $\begin{array}{l}6 \text { weeks, } M, \text { October } \\
S \text { aureus: } 3 / 16 \\
S \text { mitis: } 1 / 15\end{array}$ & $\begin{array}{l}6 \text { weeks, } M \text {, October } \\
M(B) \text { catarrhalis a\$: } 4 / 10 \\
M(B) \text { catarrhalis b\$: } 10 / 10^{\star}\end{array}$ \\
\hline 9 & $\begin{array}{l}4 \text { weeks, } M, \text { July } \\
\text { E coli: } 10 / 11^{\star} \\
S \text { agalactiae: } 0 / 10\end{array}$ & $\begin{array}{l}2 \text { weeks, } M, \text { July } \\
S \text { aureus: } 2 / 10\end{array}$ \\
\hline 10 & $\begin{array}{l}21 / 2 \text { weeks, } M \text {, January } \\
S \text { sanguis: } 0 / 10 \\
S \text { aureus: } 2 / 10\end{array}$ & $\begin{array}{l}2 \text { weeks, } M, \text { January } \\
S \text { aureus: } 1 / 11 \\
C \text { hofmannii: } 1 / 11\end{array}$ \\
\hline 11 & $\begin{array}{l}20 \text { weeks, } M, \text { November } \\
E \text { coli: } 10 / 10^{\star} \\
S \text { mitis: } 3 / 10 \\
\text { Candida humicola: } 0 / 10\end{array}$ & $\begin{array}{l}20 \text { weeks, } M \text {, November } \\
M(B) \text { catarrhalis: } 2 / 11 \\
C \text { hofmannii: } 1 / 10\end{array}$ \\
\hline 12 & $\begin{array}{l}19 \text { weeks, } \mathrm{F}, \text { February } \\
S \text { aureus: } 6 / 10^{\star} \\
\text { H influenzae I: } 10 / 10^{\star}\end{array}$ & $\begin{array}{l}19 \text { weeks, F, February } \\
S \text { aureus: } 0 / 10\end{array}$ \\
\hline 13 & $\begin{array}{l}17 \text { weeks, } M, \text { November } \\
H \text { parainfluenzae: } 9 / 10^{\star} \\
\text { Kl aerogenes: } 9 / 10^{\star}\end{array}$ & $\begin{array}{l}15 \text { weeks, } M, \text { November } \\
H \text { influenzae: } 10 / 10^{\star} \\
S \text { pneumoniae } 2: 1 / 10 \\
M(B) \text { catarrhalis: } 0 / 10\end{array}$ \\
\hline 14 & $\begin{array}{l}6 \text { weeks, } M, \text { January } \\
S \text { aureus: } 2 / 10 \\
H \text { influenzae I: } 11 / 11^{\star} \\
C \text { albicans: } 0 / 10\end{array}$ & $\begin{array}{l}6 \text { weeks, } M, \text { January } \\
E \text { coli: } 12 / 12^{\star} \\
S \text { aureus: } 0 / 11\end{array}$ \\
\hline 15 & $\begin{array}{l}111 / 2 \text { weeks, F, December } \\
S \text { aureus: } 3 / 12 \\
\text { Proteus mirabilis: } 11 / 11^{\star} \\
S \text { epidermidis: } 1 / 11\end{array}$ & $\begin{array}{l}9 \text { weeks, F, December } \\
S \text { aureus: } 1 / 10 \\
S \text { sanguis: } 1 / 10\end{array}$ \\
\hline 16 & $\begin{array}{l}9 \text { weeks, } \mathrm{F}, \text { January } \\
\text { S intermedius: } 1 / 10 \\
\text { Kl oxytoca: } 9 / 10^{\star}\end{array}$ & $\begin{array}{l}10 \text { weeks, } \mathrm{F} \text {, January } \\
C \text { hofmannii: } 0 / 15 \\
S \text { epidermidis: } 1 / 22\end{array}$ \\
\hline 17 & $\begin{array}{l}29 \text { weeks, } \mathrm{F}, \text { October } \\
\text { Kl pneumoniae: } 12 / 12^{\star} \\
S \text { mitis: } 0 / 12 \\
M(B) \text { catarrhalis: } 0 / 10\end{array}$ & $\begin{array}{l}22 \text { weeks, } \mathrm{F}, \text { October } \\
E \text { coli: } 10 / 10^{\star} \\
H \text { influenzae } \mathrm{I}: 11 / 11^{\star} \\
S \text { sanguis } \mathrm{II}: 1 / 20\end{array}$ \\
\hline 18 & $\begin{array}{l}5 \text { weeks, } M, \text { December } \\
S \text { sanguis: } 0 / 11\end{array}$ & $\begin{array}{l}6 \text { weeks, } M, \text { December } \\
S \text { epidermidis: } 0 / 10 \\
C \text { hofmannii: } 0 / 15 \\
S \text { aureus: } 0 / 10 \\
S \text { mitis: } 1 / 10\end{array}$ \\
\hline 19 & $\begin{array}{l}11 \text { weeks, F, February } \\
\text { Kl aerogenes: } 10 / 15^{\star} \\
\text { Candida parapsilosis: } 1 / 10 \\
\text { S aureus as: } 2 / 11 \\
\text { S aureus b\$: } 0 / 10 \\
S \text { mitis: } 0 / 10\end{array}$ & $\begin{array}{l}121 / 2 \text { weeks, } F, \text { February } \\
S \text { mitis: } 0 / 10 \\
S \text { aureus: } 0 / 10\end{array}$ \\
\hline 20 & $\begin{array}{l}12 \text { weeks, } M, \text { October } \\
S \text { aureus: } 0 / 10 \\
C \text { xerosis: } 0 / 15\end{array}$ & $\begin{array}{l}121 / 2 \text { weeks, } \mathrm{M}, \text { October } \\
\text { H influenzae } \mathrm{I}: 11 / 11^{\star} \\
C \text { hofmannii: } 1 / 11\end{array}$ \\
\hline 21 & $\begin{array}{l}111 / 2 \text { weeks, } M, \text { May } \\
\text { S aureus: } 2 / 10 \\
\text { H parainfluenzae: } 10 / 10^{\star} \\
\text { Ent cloacae: } 10 / 10^{\star} \\
\text { S sanguis II: } 3 / 11\end{array}$ & $\begin{array}{l}12 \text { weeks, } M, \text { May } \\
S \text { aureus: } 0 / 10 \\
S \text { sanguis II: } 0 / 10 \\
S \text { sanguis } I I: 0 / 10\end{array}$ \\
\hline 22 & $\begin{array}{l}19 \text { weeks, } M, \text { December } \\
S \text { aureus: } 0 / 11 \\
\text { Ent faecalis: } 2 / 11 \\
S \text { mitis: } 0 / 10\end{array}$ & $\begin{array}{l}20 \text { weeks, } M, \text { December } \\
C \text { hofmannii: } 0 / 10 \\
M(B) \text { catarrhalis: } 2 / 10 \\
S \text { salivarius: } 0 / 10\end{array}$ \\
\hline
\end{tabular}

†The results of the toxigenicity testing are recorded in the table as the number of chicks killed out of the total number of chicks used in the test. Those isolates marked $\star$ were lethal to more than half of the chick embryos tested and are considered to be lethally toxigenic in this test system.

Different isolates of the same species.

$S$ salivarius, $S$ intermedius, and $S$ pyogenes refer to Streptococcus sp.

†Bergey's Manual points out that the name Corynebacterium hofmannii, although widely used, has not been validly published. The Manual refers to this species as $C$ pseudodiphtheriticum. members of the flora. The significance of these findings was determined.

Data in table 1 were statistically analysed to see if the likelihood of harbouring a toxigenic micro-organism was significantly greater in SIDS cases than in normal infants. Thirty six per cent of the latter group harboured one or more toxigenic organisms compared with $68 \%$ of SIDS cases. This difference was significant ( $p<0.05$ ) when comparison was made using a one-tailed Fischer's exact test. SIDS cases were significantly more likely to have a lethally toxigenic constituent of the nasopharyngeal flora than normal infants.

\section{TOXIGENIC ISOLATES AND SIDS}

The observed number toxigenic isolates found in samples from SIDS cases was compared with the number expected using the method indicated by Breslow and Day. ${ }^{4}$ The isolates from each SIDS case and its matched control were treated as a separate group. The expected number of toxigenic isolates from the SIDS case is calculated given the numbers of isolates in the SIDS case and the control, and the total number of lethal isolates in both the SIDS case and its control. Using the same approach, the variance in the number of toxigenic isolates in the SIDS case can be calculated. The mean and variance of the total number of toxigenic isolates in all SIDS cases in the sample is calculated by summing the means and variances over all the SIDS cases in the sample.

Summing over all the SIDS cases, the total number of toxigenic isolates observed was 19 . The expected total number was 16.47 and the variance of the total number was 5.73 on the null hypothesis of no difference in the prevalence of toxigenic isolates between SIDS cases and controls. In the above circumstances it is reasonable to assume that the total number of toxigenic isolates will more or less follow a normal distribution.

Because $z=(19-16 \cdot 47) / \sqrt{ } 5 \cdot 73=1 \cdot 057$, this corresponds to a probability of $p=0 \cdot 15$, using a one-sided test; if a continuity correction were used the corresponding probability would be even larger. This approach is equivalent to that using the $\chi^{2}$ distribution with one degree of freedom. ${ }^{4}$ Hence it cannot be concluded that the proportion of toxigenic isolates out of all isolates is significantly higher in SIDS cases compared with controls.

ENDOTOXIN CONCENTRATIONS AND COT DEATHS Endotoxin concentrations in crude toxin preparations from SIDS cases and from normal infants were compared separately for Gram positive and Gram negative organisms. For Gram positive organisms the difference was not significant ( $p=0.67$ ) using Student's $t$ test $(t=0.43, d f=66)$. For Gram negative organisms the difference in endotoxin concentrations was not significant ( $p=0.42)$, using Student's $t$ test, $\mathrm{t}=-0 \cdot 82$, df $=31$. Both the above tests are two sided (table 3 ).

When the results from SIDS cases and controls were combined it was clear that endotoxin concentrations for Gram negative organisms were significantly different 
Table 2 Lethality to 11 day old chick embryos of crude toxin preparations from predominant nasopharyngeal microbial species isolated from 22 SIDS and normal infants

\begin{tabular}{|c|c|c|}
\hline \multirow[b]{2}{*}{ Species tested } & \multicolumn{2}{|c|}{ Toxigenicity (lethal/total No of strains) } \\
\hline & SIDS & Normal \\
\hline$S$ aureus & $3 / 16$ & $0 / 10$ \\
\hline S epidermidis & $0 / 3$ & $0 / 3$ \\
\hline$S$ intermedius & $0 / 1$ & - \\
\hline$S$ mitis & $0 / 6$ & $0 / 2$ \\
\hline$S$ pneumoniae & $0 / 2$ & $0 / 3$ \\
\hline$S$ sanguis & $0 / 3$ & $0 / 4$ \\
\hline$S$ agalactiae & $0 / 1$ & - \\
\hline$S$ salivarius & - & $0 / 1$ \\
\hline$L$ lactis cremoris & $0 / 1$ & - \\
\hline Ent faecalis & $0 / 1$ & - \\
\hline Chofmannii & - & $0 / 8$ \\
\hline C striatum & - & $0 / 1$ \\
\hline Cxerosis & $0 / 1$ & - \\
\hline H influenzae & $2 / 2$ & $4 / 4$ \\
\hline H parainfluenzae & $3 / 3$ & $1 / 1$ \\
\hline$M(B)$ catarrhalis & $0 / 1$ & $3 / 8$ \\
\hline Kl oxytoca & $2 / 2$ & - \\
\hline Kl aerogenes & $3 / 3$ & - \\
\hline Kl pneumoniae & $1 / 1$ & - \\
\hline E coli & $3 / 3$ & $3 / 3$ \\
\hline Ent aerogenes & - & $1 / 1$ \\
\hline Ent cloacae & $1 / 1$ & -1 \\
\hline$P$ mirabilis & $1 / 1$ & - \\
\hline Candida and Torulopsis & $0 / 5$ & - \\
\hline Total No lethal/total No tested & $19 / 57$ & $11 / 49$ \\
\hline
\end{tabular}

†Bergey's Manual points out that the name Corynebacterium hofmannii, although widely used, has not been validly published. The Manual refers to this species as $C$ pseudodiphtheriticum.

Table 3 Endotoxin concentrations and cot deaths

\begin{tabular}{lllll}
\hline Gram type & Group & Mean & (SD) & $n=$ \\
\hline Positive & SIDS case & $16 \cdot 4$ & $(14 \cdot 2)$ & 36 \\
& Control & $15 \cdot 0$ & $(10.4)$ & 32 \\
Negative & SIDS case & $26 \cdot 0$ & $(12 \cdot 9)$ & 17 \\
& Control & $29 \cdot 1$ & $(7 \cdot 3)$ & 16 \\
\hline
\end{tabular}

Table 4 Endotoxin concentrations and gram reaction

\begin{tabular}{llll}
\hline Gram type & Mean & $(S D)$ & $n=$ \\
\hline Positive & $15 \cdot 7$ & $(12.5)$ & 68 \\
Negative & 27.5 & $(10.5)$ & 33 \\
\hline
\end{tabular}

$(p=0.0001)$ from those from Gram positive organisms (table 4), using Student's $t$ test $(t=-4.66, \mathrm{df}=99)$. The test is a two-sided test.

The above calculations and those of Spearman's correlation coefficient below were carried out using the SPSS-X package of programs.

\section{ENDOTOXIN CONCENTRATIONS AND LETHALITY}

The correlation between endotoxin concentrations and the lethality of the samples in the chick embryo test system was investigated (figure). For Gram positive organisms, the Spearman correlation coefficient between endotoxin concentration and proportion of chick embryos killed was $r_{s}=-0.048$, $\mathrm{p}=0 \cdot \mathbf{7 0}$. For Gram negative organisms, the Spearman correlation coefficient was $r_{s}=$ $-0.173, p=0.34$. The two probabilities above are from two sided tests. In both types of organisms there was no evidence of a correlation between the endotoxin concentration and the lethality of the sample.

\section{Discussion}

One problem which besets all who investigate SIDS is the lack of matched necropsy controls.

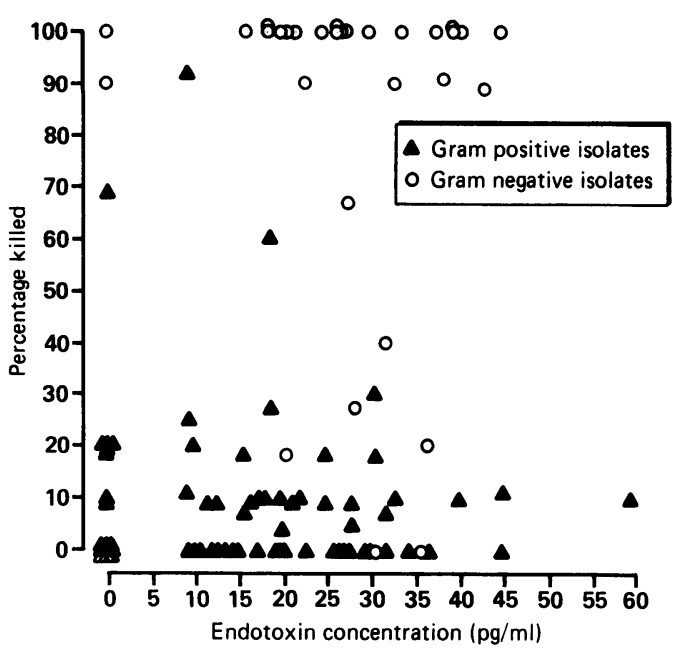

Correlation between lethality (per cent chick embryos killed by toxin) and endotoxin concentration in toxin preparations from Gram positive and Gram negative organisms.

This arises because so few infants die during the first year of life without infection playing a part. Our "control" group was, in reality, a group of matched healthy infants. ${ }^{14}$ This represents, as in other studies, a concession to expedience. The matching itself is close but not exact; perfection would require same day matching, but this would be neither feasible nor necessary. No study suggests SIDS is that closely related to age.

In choosing the chick embryo as the bioassay system, it was appreciated that toxicity is a function of the test system used. For example, germ free rats used in our earlier work ${ }^{19}$ are peculiarly resistant to endotoxin, whereas the chick embryo test system is much more sensitive. Different tissue culture systems display differing sensitivities to specific toxins and also fail to detect effects on whole biological systems as opposed to effects on specific cell types. The relative failure of $S$ aureus to prove toxigenic in our hands is paralleled by the finding ${ }^{19}$ that TSST -1 at concentrations as high as $100 \mu \mathrm{g} / \mathrm{ml}$ has no effect on chick embryos. In fact, this toxin is highly potent, even in adults, and must be considered a candidate toxin to be implicated in SIDS by the common bacterial hypothesis.

Some of the $S$ aureus isolates tested for lethal toxigenicity in this study have been tested for production of specific enterotoxins and TSST1 at the Central Public Health Laboratory, Colindale. Two of the three $S$ aureus isolates from SIDS babies that were positive (for lethality to chick embryos) did not produce detectable concentrations of any of the panel of known enterotoxins or TSST-1. Other staphylococcal toxins ( $\alpha$ - and $\lambda_{-}$) may have been elaborated.

The results show (table 2) that in general Gram negative Enterobacteriaceae, Neisseriaceae, and Haemophilus and related species are lethal to the chick embryos. $H$ influenzae and $H$ parainfluenzae isolated from SIDS cases or normal infants were invariably lethal (all nine isolates); Moraxella (Branhamella) catarrhalis was not always lethal (three out of 
nine isolates tested in total). Chick embryos are sensitive to bacterial endotoxin..$^{21}$ A positive result in the chick embryo assay system indicates that there is at least one lethally toxigenic substance of a molecular weight above 10-12 000 (approximate exclusion limit of dialysis membrane) in the crude toxin preparation tested. This might include endotoxin. The route to sudden infant death seems likely to occur via a common pathway and may be a rare consequence of overwhelming bacterial toxaemia. ${ }^{13}$ Toxins such as TSST1 , although potent as a single agent, become much more potent when acting in synergy with endotoxin. ${ }^{22}$ The potential contribution of endotoxin to SIDS should not be excluded and might provide a molecular explanation for the enhanced effect of combined species in germ free rats. ${ }^{19}$

The occurrence of a highly potent combination of toxic substances acting in synergy is attractive in the context of SIDS. It seems unlikely that a single species, or toxin, is responsible for the syndrome. If a number of toxic agents were involved the mechanism of enhanced toxicity could be different for each of the toxins. recent work has shown that the toxicities of staphylococcal $\alpha$ and $\gamma$ toxins, endotoxin and diphtheria toxin to ferret neonates was enhanced by prior influenza virus infection. ${ }^{23}$ Furthermore, the release of intracellular radiolabel from cells in vitro by staphylococcal $\alpha$-toxin, diphtheria toxin and streptolysin $S$ was significantly enhanced if the cells were previously infected with influenza virus. ${ }^{24}$ Such enhancement of synergy ${ }^{22}$ may be caused by uptake of toxin by susceptible tissues being promoted by-for example, influenza virus. Alternatively, the induced increase in cellular permeability may lead to release of inflammatory mediators and other physiologically active materials from cells.

The isolation of toxigenic micro-organisms from SIDS cases shown by the findings of this study and others, ${ }^{811} 12$ and the demonstration of toxin (TSST-1) in renal tubular cells of some SIDS cases $^{25}$ provide good evidence for the pathogenic role of bacterial toxins in SIDS. Increasingly, evidence suggests that SIDS is caused by different toxins acting in synergy. ${ }^{13}$ Certainly combinations of nasopharyngeal $S$ aureus and $E$ coli have been shown to produce sudden rapid death in germ free rats. ${ }^{19}$ The chick embryo assay system would be well suited to test combinations of toxins and we intend to investigate further the toxigenicity of the nasopharyngeal microbial flora, although biomolecular separation of the crude toxin preparations and characterisation of the constituent fractions is clearly a priority. This study therefore provides additional support for the hypothesis that the toxins of commonly occurring bacteria are involved in the pathogenesis of SIDS.

The results of our statistical analyses in no way conflict with the common bacterial toxin hypothesis. ${ }^{13}$ The present data show that while the likelihood of harbouring a toxigenic nasopharyngeal organism is higher in SIDS cases than in normal infants, the individual organ- isms found are not significantly different with respect to toxigenicity. Correspondingly, SIDS isolates are not more likely to produce endotoxin (in cell free toxin preparations) than isolates from normal infants. These findings imply that it is the proliferation of species in the nasopharynx or the lack of protective immunity, or both that may lead to cot death.

We thank the Foundation for the Study of Infant Death for their support and Dr Susan Lee, who devised the method of toxigenicity testing of SIDS isolates in chick embryos.

1 Anonymous. Foundation for the Study of Infant Deaths (cot death research and support) Newsletter 40 August 1991:2.

2 Bergman A, Beckwith JB, Ray CG. Sudden Infant Death Syndrome. Proceedings of the Second International Conference on Causes of Sudden Death in Infants. Washington: University of Washington Press, 1969.

3 Beckwith JB. The sudden infant death syndrome. Curr Prob Pediatr 1973;3:1-36.

4 Breslow NE, Day NE. Statistical methods in cancer research. Vol 1. Lyon: IARC, 1980:138.

5 Valdes-Dapena MA. Sudden and unexpected death in infancy; a review of the world literature 1954-66. infancy; a review of the

6 Williams AL, Uren CE, Bretherton L. Respiratory Viruses and Sudden Infant Death. Br Med J 1984;288:1491-3.

7 Milner AD. Recent theories on the cause of cot deaths. $B r$ Med J 1987;295:1366-8.

8 Arnon SS, Midura TF, Damus K, Wood RM, Chin J. Intestinal infection and toxin production by Clostridium botulinum as one cause of sudden infant death syndrome. Rev Infect Dis 1978;6:S193-S201.

9 Bacon CJ, Scott D, Jones P. Heatstroke in well-wrapped infants. Lancet 1979;i:422-5.

10 Fleming PJ, Gilbert R, Azaz Y, et al. Interaction between bedding and sleeping position in the sudden infant death syndrome: a population based case-control study. $\mathrm{Br} \mathrm{Med}$ syndrome: a populat

11 Sonnabend OAR, Sonnabend WFF, Krech U, Molz G, Sigrist T. Continuous microbiological and pathological study of 70 sudden and unexpected infant deaths: toxigenic intestinal Clostridium botulinum infection in 9 cases of sudden infant death syndrome. Lancet 1985;i:237-41.

12 Bettleheim KA, Goldwater PN, Dwyer BW, Bourne AJ, Smith DL. Toxigenic Escherichia coli associated with sudden infant death syndrome. Scand J Infect Dis 1990;22:467-76.

13 Morris JA, Haran D, Smith A. Hypothesis: common bacterial toxins are possible cause of sudden infant death syndrome. Med Hypth 1987;22:211-22.

14 Telford DR, Morris JA, Hughes P, et al. The nasopharyngeal bacterial flora in the sudden infant death syndrome. $J$ Infect 1989;B18:125-30.

15 Jones D, Collins MD. Irregular, nonsporing Gram-positive rods. In: Sneath PHA, Mair NS, Sharpe ME, Holt JG, eds. Bergey's manual of systematic bacteriology. Baltimore: Williams \& Wilkins, 1986:1261-1434.

16 Lee S, Barson JA, Drucker DB, Morris JA, Telford DR. Lethal toxins from cot death (SIDS) isolates-a detection system using embryonated eggs. J Med Micobiol system using

17 McKendrick N, Drucker DB, Morris JA, Telford DR. Toxin production by bacteria isolated from cases of sudden infant death syndrome (SIDS). J Med Micobiol 1989;30: $x$.

18 Hallander HO. Production of large quantities of enterotoxin $\mathrm{B}$ and other staphylococcal toxins on solid media. Acta Path Microbiol Scandinavica 1965;63:299-305.

19 Lee S, Barson AJ, Drucker DB, Morris JA, Telford DR. Lethal challenge of gnotobiotic weanling rats with bacterial isolates from cases of sudden infant death syndrome (SIDS). J Clin Pathol 1987;40:1393-6.

20 Eichhorn EA. A technique for the intravenous inoculation of chick embryos. Science 1940;92:245-6.

21 Smith RT, Thomas $L$. The lethal effect of endotoxins on the chick embryo. J Exp Med 1956;104:217-31.

22 de Azevado JCS, Lucken RN, Arbuthnott JP. Effect of toxic shock syndrome toxin 1 on chicken embryos. Infect Immun 1985;47:710-12.

23 Jakeman KJ, Rushton DI, Smith H, Sweet C. Exacerbation of bacterial toxicity to infant ferrets by influenza virus: possible role in sudden infant death. $J$ Infect Dis 1991;163:35-40.

24 Jakeman KJ, Smith H, Sweet C. Influenza virus enhancement of membrane leakiness induced by staphylococcal $\alpha$ toxin, diphtheria toxin and streptolysin S. J Gen Virol $\alpha$ toxin, diphtheri

25 Newbould MJ, Malam J, McIllmurray JM, Morris JA, Telford DR, Barson AJ. Immunohistological localisation of staphylococcal toxic shock syndrome toxin (TSST-1) antigen in sudden infant death syndrome. J Clin Pathol 